\title{
Considering Public Interest Regulatory Theory: Investigating the Links between Regulatory Emphasis and Effectiveness
}

\author{
Mike Potter $^{1}$ \\ ${ }^{1}$ Department of Government \& Justice Studies, Appalachian State University, Boone, NC, USA \\ Correspondence: Mike Potter, Anne Belk Hall, ASU Box 32107, Department of Government \& Justice Studies, \\ Appalchian State University, Boone, NC., 28708-2107, USA. Tel: 1-828-262-6350. E-mail: \\ pottermr1@appstate.edu
}

Received: April 24, 2013 Accepted: May 9, 2013 Online Published: September 29, 2013

doi:10.5539/par.v2n2p37 URL: http://dx.doi.org/10.5539/par.v2n2p37

\begin{abstract}
This article explores the linkages between public-interest and regulatory theory. By examining academic scholarship relating to effectiveness and regulatory theory, this article proposes that there are links between agencies with a public-interest orientation and effective regulatory action. In order to examine this relationship this article analyzes three federal financial services regulators and their varying levels of effectiveness. In order to do this analysis focuses on three types of regulatory actions. These are technical, clientele, and public interest interventions. Next, the article looks for linkages among variations in regulatory style and agency effectiveness (in these cases as measured by regulatory ability to prevent the failures of supervised institutions). The analysis concludes by stating that there does appear to be some evidence for linkage between an agency's public interest orientation and their ability to effectively supervise a regulated community.
\end{abstract}

Keywords: public interest, regulatory theory, regulatory effectiveness

\section{Introduction}

Regulators have varying ways that they relate to the communities they supervise. Different regulators and policy areas also have varying administrative tools that allow them to influence the behavior of those they police. These strategies or points of regulatory emphasis can drastically change agencies orientations towards those they are tasked with supervising. Yet, there has been little research, both theoretical and applied that investigates the specific dynamics of regulatory orientation and effectiveness (Aberbach, 1990; Bernstein, 1955; Eisner, 2000; Katzmann, 1980; Meier, 1985).

This article theorizes about and explores the impact of agency orientation towards supervisory community on regulatory effectiveness. I start by proposing that regulators more inclined to focus on engaging in public interest and technical policymaking rather than empowering their regulated community are more effective at policing behavior (Katzmann, 1980). By focusing on technical and public interest issues agencies avoid captured relationships with their supervised institutions. Furthermore, by engaging in dialogue that reflects public interest values, rather than the values of their regulated communities, regulators can gain perspective allowing them to balance the concerns of their supervisory institution with those of the public (Goodsell, 1990).

The focus on public values by regulators may better allow them to separate the narrow interests of the regulated community (in this analysis clientele interests), from the broader systemic understanding of the role of regulators (in this project referred to as public interest). However, this task can be challenging. Many regulators are structured with ambiguous mandates from Congress (Aberbach, 1990). Furthermore, gauging the effectiveness of regulatory agencies is also fraught with peril. Agencies exist in complex policy environments and have many expectations from both public and private sector actors that seldom agree what precisely their role should be. Nevertheless, there are some regulatory contexts where one can isolate and investigate public interest, clientele interests and tie that to a broader understanding of agency effectiveness (Baumgartner \& Jones, 2005; Feldmann, 2005; Goodsell, 1990).

At least in part, this analysis hinges on an understanding of regulatory effectiveness among financial services regulators that primarily focuses on preventing systemic risk. The term systemic risk is essential to understanding the development of financial services regulators. Kaufman and Scott (2003) define systemic risk as: 
... the risk or probability of breakdowns in an entire system, as opposed to breakdowns in individual parts or components, and is evidenced by comovements (correlation) among most or all the parts. Thus, systemic risk in banking is evidenced by high correlation and clustering of bank failures in a single country, in a number of countries, or throughout the world" (p. 372).

This analysis links the ability to prevent systemic risk with preventing the failures of regulated institutions. Despite many common features, during the years 1998 to 2008 there is considerable variation among the failure rates of supervised institutions at three federal financial services regulators (see Figure 1 below).

Figure 1: Failure Rates Expressed as Percentage of Regulated Institutions by Agency, 1998 to 2008

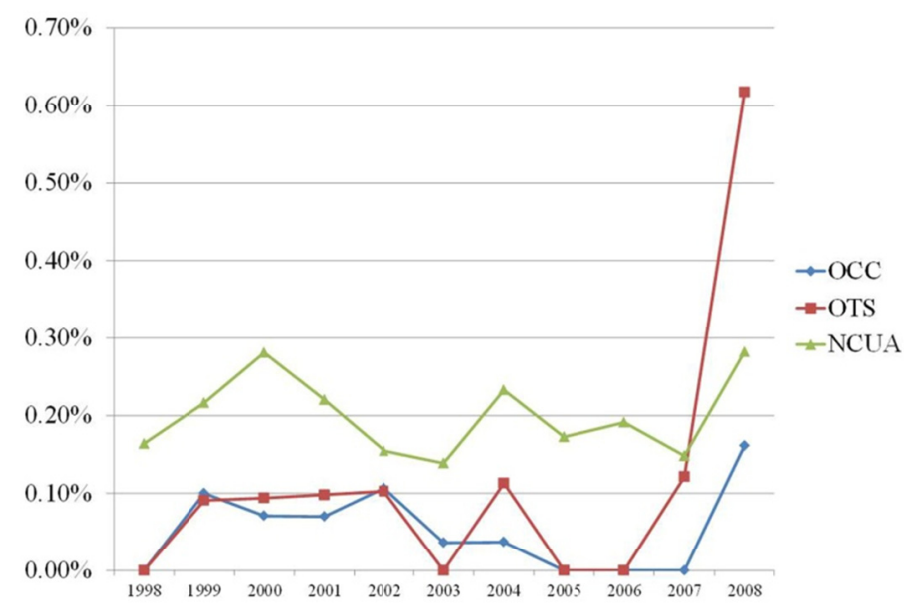

The three agencies that are the subject of this study are the National Credit Union Administration (NCUA), Office of the Comptroller of the Currency (OCC), and the Office of Thrift Supervision (OTS). All three agencies are federal financial services regulators. All three agencies deal with similar issues of balancing political, interest group, and consumer concerns. Yet, each agency has had slightly different levels of effectiveness. These varying failure rates lead to the research question that is the focus of this analysis. To this end, the question that underpins the study is:

Does a focus on public interest lead to greater effectiveness among financial services regulators? If so, how?

In order to understand the variation among the failure rates of similarly positioned regulatory agencies, I theorize and explain the variation by examining charter attention and attraction strategies of each regulator and its regulatory emphasis. This article argues that there are important links between the orientation that regulatory agencies toward their supervised communities and regulatory effectiveness (Goodsell, 2011; Hammond \& Knott, 1988; S. a. M. K. C. Hoffmann, 2010) .

The NCUA is the primary regulator of federally chartered credit unions and the National Credit Union Share Insurance Fund (NCUSIF). The now defunct OTS regulated savings institution. While the final agency analyzed in this work, the OCC is tasked with overseeing national banks. Each regulator is forced to negotiate cycles of economic boom and bust, while advocating for their regulated institutions and attempting to safeguard the financial services system as a whole. According to previous research, I expect that agencies most oriented towards public and technical interest in their communications with their regulated communities should have been the most effective preventers of systemic risk ("National Credit Union Administration Website ", 2010; "Office of the Comptroller of the Currency Website," 2011; "Office of Thrift Supervision Website," 2011).

Financial services regulators that effectively incorporate public values into their communications with their regulated communities should have better been able to avoid ignoring and deferring to troubled institutions that then eventually would fail. This proposed framework argues that there is little differentiation between technical and public interest compliance and both forward the ability of regulators to prevent the failures of their supervised institutions (Goodsell, 1990). 


\section{Method}

This article first proposes a theory of public interest regulation. Next it applies the theory to a case comparison of three financial services regulators Through this limited case comparison, this analysis is structured to preliminarily apply the theory of public interest regulation. In order to do I have selected three financial services regulators that have overlapping jurisdiction. By selecting these cases, I have controlled for considerable variance and am better able to focus the analysis on the specific impact of the variations in public interest orientation and regulatory effectiveness (Yin, 2009).

Applying the theory of public interest regulation in this analysis rests on understanding the breakdown of agencies policy statements, speeches and testimony. In order to do this I examine the NCUA's policy statements followed by speeches and testimony of their political appointees, followed by the OCC and finally the OTS. The analysis is structured to show whether or not there are linkages in the public interest rates of speeches and testimony /policy statements and overall regulatory effectiveness.

\subsection{Understanding the Regulatory Context}

In order to fully understand regulatory environment within which federal financial services regulators operate one must be familiar with two important dynamics that impact the ability of agencies to operate. These dynamics are; self-funding and the competitive equilibrium of powers granted regulatory institutions. Federal financial services regulators are funded entirely by fees charged to their regulated institutions (The OCC's Preemption Rules, 2006). While allowing the burden of the cost of financial services regulation to be shouldered by banks and credit unions, this dynamic also creates incentives for regulators to cater to their supervised institutions.

The second dynamic underpinning the regulatory context for financial services agencies relate to the ability of regulated institutions to change charters and effectively move from one regulator to another. Therefore, if a regulator does not grant broad enough authority to engage in diverse and emerging financial strategies, institution may switch charters and the regulated by a more permissive agency (Dell'Ariccia, 2001; McCabe, Butterfield, \& Trevino, 2006; Scott, 1977).

The three federal regulators work toward an equilibrium between the general equality of and the empowering of their regulated institutions. While many contended that the charter competition decreases regulation on their institutions do not appear to be the case. Rather, the most successful regulator and the one that has been growing most significantly in number of institutions regulated is the most stringent of the three regulators. What occurs is a general parity between the powers granted the regulated institutions (Weinberg, 2002).

\section{Proposing a Theory of Public Interest Regulation}

Figure 2: Proposed Relationship between Regulatory Emphasis and Effectiveness

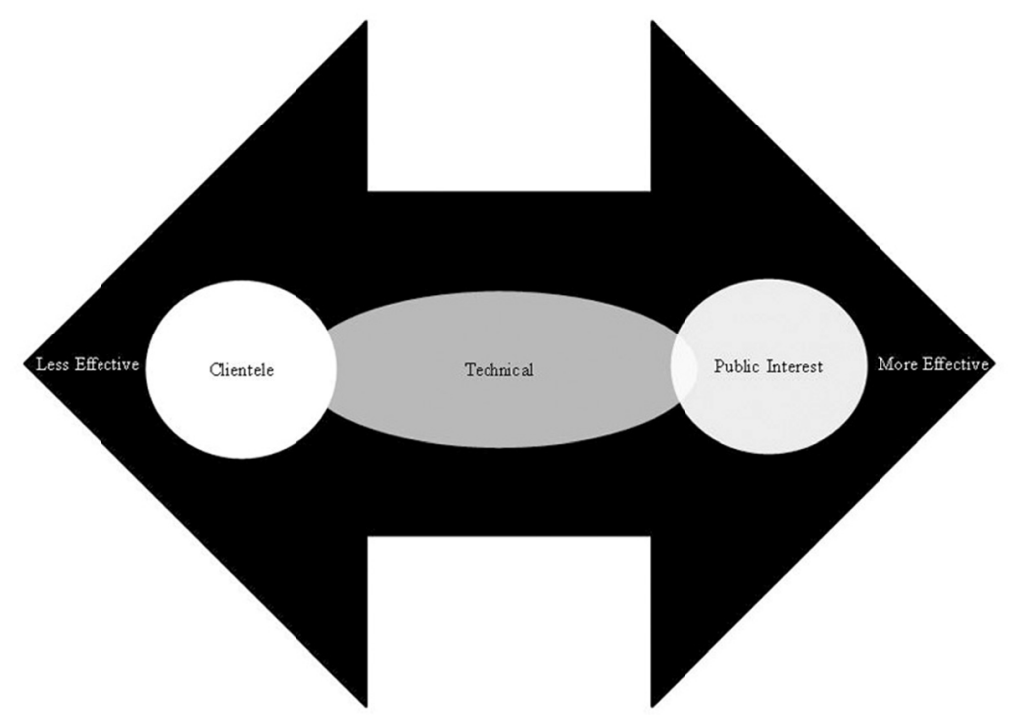

In order to test this proposed relationship between regulatory emphasis on effectiveness this analysis examines the strategies among federal regulators to encourage other institutions to be attracted to their charter and examines the precise composition of regulatory policy statement and their inclination towards public interest, technical 
compliance, and clientele interests (see Figure 2).

The relationships theorized above in Figure 2 relates to level of effectiveness and the type of regulatory interventions that agencies undertake. I theorize that more effective agencies engage in public interest and technical types of policy communications and interventions more frequently than clientele oriented policies. While all regulatory agencies engage in varying levels in all three types of policies those that are most effective at supervising regulated communities focus less on empowering their supervised institutions and more on giving technical guidance or constraining regulated entities behavior through formal and informal policy processes.

Essentially, I argue that there is a linear relationship among regulatory and effectiveness. The least effective regulators focus on clientele issues and most effective focus on public interest. While regulators of moderate effectiveness focus on technical issues (however there are debatable amount of overlap between technical guidance and clientele and public interest emphases).This expectation is drawn from a variety of research that focuses on the nature of regulatory capture specifically among financial services institutions (Boehm, 2007; Hardy, 2006; Laffont, 1991; Smyth, 2009; Thomas, Soule, \& Davis, 2010; Woodward, 1998)and the failures within government that have led to previous banking crises (Moe, 1991; Buiter, 2008; Johnson, 2010; States, 2011; Whalen, 2008).

This analysis proposes a classification of types of policy statements. It is based on the distinction drawn by regulatory capture theorists that a captured system exists for the benefit of a clientele group and not for the public interest. Therefore, testimonies, speeches, informal rulemaking, and formal rulemakings are classified for the purpose of understanding the client groups to which policies are aimed. The three classifications are clientele, the public interest, and technical statements. This analysis treats capture as a subset of overall agency behavior. Rather than simplistically viewing capture, it contends that agencies move in and out of captured relationships based on legislative attention.

\subsubsection{Clientele Policies}

Clientele policies are narrowly tailored directly toward the regulated community. In this study that would represent national banks for the OCC, thrift institution for the OTS, and federally insured credit union for the NCUA. Clientele policy is tailored to directly benefit the regulated community in an obvious way. Referring back to the agency theory that underpins the relationship between the actors within the policy environment, clientele policy represents a very low degree of goal differentiation and information asymmetry between the regulator and regulated institutions. This is because the regulators frequently act as an expressed advocate for its regulated institutions.

The most common examples of a clientele policy are attempts at regulatory relief which lessen the regulatory burden on regulated institutions. Other types of clientele policy are statements aimed at establishing the importance of the regulated industry and statements geared towards expansion of business powers for regulated institutions. Within the financial services regulatory environment which has self-funded regulators pushes toward efficiency at expense of effectiveness and equity also fit this criteria.

\subsubsection{Public Interest Policies}

Public interest policy is distinguished by pertaining to more general and consumer oriented issues. Frequently these policies are espoused by regulators acting in a policing role. Furthermore, these policies would not be championed by most of the regulated institutions. Agency theory as applied to public interest policy would have a high level of goal differentiation and a high level of information asymmetry. This is because public interest policies focus on consumer issues and systemic risk that interest group advocacy efforts do not focus on. Examples of public interest policy would be a regulator making statements regarding predatory lending, financial literacy, or the safety and soundness of the financial system. While public interest policy may closely mirror cleverly disguised clientele policy, the distinction between the two generally rests in the constituency at which the policy is aimed. Policies aimed at the general public and not financial institutions employees will generally be public interest oriented.

\subsubsection{Technical Policies}

Technical policies are statements from the regulator to the regulated community of a technical nature. Generally these statements deal with sophisticated guidance relating to compliance issues. While many technical policy issues may in fact be cleverly disguised clientele policies also, the distinction lies in the audience. Agency theory posits that technical policymaking by regulatory agencies would generally have a high level of information asymmetry and a low-level of goal differentiation. Generally these policymaking are aimed at technical forms of guidance clarifying and crafting policy issues that the regulated institution in good faith has attempted to comply 
with. An example of technical policymaking would be accounting rules and guidance relating to internal controls or the manner which capital should be counted by call reports.

In recent years there has become less difference between the powers granted by different financial services charters. Historical differences in power, capital requirements, and lending limit between federally and state-chartered institution have converged. Therefore, the remaining divergence relates to federal preemption and the lower supervisory costs of state-chartered regulators (Blair \& Kushneider, 2006).

During the last two decades, all financials services regulators have focused on reducing the costs of supervision. Regulators attempted to reduce the cost of supervision. They reduced assessment fees and prevented the indexing of the assessment schedule for inflation. The agency also put in place a minimum supervisory fee for small institutions. The authors argued that the agency shifted the funding of the agency from a larger institution to the smaller ones. This placed a substantial burden on smaller institutions to fund the OCC's activities (Blair \& Kushneider, 2006). Several scholars have argued that the main dynamic influencing charter choice are the broadest range of powers offered at the lowest regulatory cost (Estache, 1999; Martimort, 1999). The focus on parity among regulated institutions and cost-effectiveness has at least in part been coordinated by interest groups seeking to lobby financial services regulators. The interest groups that lobby financial services regulatory agencies are some of the best funded associations at the federal level. This greatly complicates the ability of the OCC, OTS, and NCUA to engage in public interest policymaking (Hammond \& Knott, 1988; Hoffmann, 2001, Hammond, 1957).

\subsection{Interest Group Context}

Each regulator has a group or groups that attempt to influence their policy. The OCC interacts most frequently with American Bankers Association and Independent Community Bankers of America. The OTS primarily caters to America's Community Bankers which recently merged with American Bankers Association. The NCUA interacts with the National Association of Federally Chartered Credit Unions and the Credit Union National Association. CUNA represents state-chartered credit unions and their primary interactions with NCUA are regarding the insurance fund.

\subsection{Charter Strategies}

The agencies that are the subject of this study each operate in a manner that allows them to accentuate the benefits of their charter and deemphasize the weaknesses. The NCUA offers the institutions it regulates the considerable advantage of the federal corporate tax exemption. However these institutions do not have access or have only limited access to the capital markets and therefore may only be funded to very conservative means. Furthermore, federal credit unions have a cap on the amount of business lending they are permitted to engage in, currently 12.25 percent of total assets. While historically NCUA has not focused on enforcing the business lending cap, it has also lobbied for institutions it regulates to have expanded business lending powers.

In many ways the OTS is caught between the true mutuality of federal credit union charter and the efficiency of the commercial bank charter. This has led to the regulator and thrift-oriented advocacy groups to push for measures that allow them to better compete with both commercial banks and federally chartered credit unions. Thrifts are subject to the "Qualified Thrift Lender Test (OTS 2010)." The test requires thrifts to keep proximately 80 percent of their assets in mortgage-oriented types of instrument. The focus on mortgage lending greatly reduces OTS regulated institutions' ability to take part in business lending but in theory should make them less likely to fail.

In order to aid thrifts competing against credit unions, the OTS has been an advocate of the subchapter S tax structure for institutions. Subchapter S allows institution to be taxed at the shareholder rather than the corporate level. However, there are strict requirements regarding the number of shareholders allowable. Attempts such as this to decrease the tax burden on OTS-regulated institutions are a curious leveler to the credit union advantage of a corporate tax exemption.

Even stranger than Subchapter S status is the mutual holding company structure. This allows mutually owned banks to offer a minority stock offering of up to 49 percent of the total capital in order to raise funds. However the majority ownership still exists as a mutual structure. Congress developed the mutual holding structure to allow mutual banks to compete with commercial banks' ability to raise capital through an initial public offering.

The OCC has been successful competing with the OTS and NCUA. Subchapter S status which is also available to national banks levels the playing field with federal credit unions. As stated previously the OCC regulated institutions generally have access to capital through stock offerings. National banks have the broadest range of powers. In recent history, OTS and NCUA regulated institutions have been forced to play catch-up with the broad granting of power to national banks. In fact the analysis of policy statements by the OCC showed the agency's preoccupation with preserving the preemption of federal bank regulators over state law (Hoffmann, 2001). 
This may be because of a recent trend for state regulators to position and sell at a lower cost regulatory alternative to the OCC. Many states have a "wildcard" statute that allows the state-chartered grant any power at national bank may have. Therefore, the OCC's best tactic for preserving its charter is to focus on the preemption of certain types of state and local laws that may be onerous for financial institutions. Generally, these are usury cap ceilings relating to predatory lending (Taylor, 2004).

Each of these regulators attempts to increase the powers granted to institutions that regulate in order to be more competitive with other charters. It is important to note that the evidence for regulatory race to the bottom is scant. What does occur, however, is an "arms race" of increased powers for the institutions overseen by each of the federal regulators. Therefore, the dynamic would be better considered a powers-oriented "race to the top" designed to reinforce competitive balance than relieving regulatory pressure. The differences between regulatory style and culture among agencies are so minimal that currently charter changes are undertaken simply on the basis of potential cost savings. This is a reason the OCC has become concerned with state regulators poaching national banks (Taylor, 2004).

\section{Applying the Theory of Public Interest Regulation}

Applying the theory of public interest regulation in this analysis rests on understanding the breakdown of agencies policy statements, speeches and testimony. In order to do this I examine the NCUA's policy statements followed by speeches and testimony of their political appointees, followed by the OCC and finally the OTS. The analysis is structured to show whether or not there are linkages in the public interest rates of speeches and testimony /policy statements and overall regulatory effectiveness. Now I will turn to the first of the three agencies in the analysis.

\subsection{NCUA}

Table 1: Breakdown of NCUA Policy Statements

\begin{tabular}{|c|c|c|c|c|c|c|}
\hline & $1999-2000$ & 2001-2002 & 2003-2004 & $2005-2006$ & $2007-2008$ & Median \\
\hline Clientele & 4 & 6 & 10 & 7 & 2 & \\
\hline Statements & $44.44 \%$ & $40.00 \%$ & $52.63 \%$ & $38.89 \%$ & $6.90 \%$ & $40.00 \%$ \\
\hline Public Interest & 1 & 3 & 3 & 4 & 12 & \\
\hline Statements & $11.11 \%$ & $20.00 \%$ & $15.79 \%$ & $22.22 \%$ & $41.38 \%$ & $20.00 \%$ \\
\hline Technical & 4 & 6 & 6 & 7 & 15 & \\
\hline Statements & $44.44 \%$ & $40.00 \%$ & $31.58 \%$ & $38.89 \%$ & $51.72 \%$ & $40.00 \%$ \\
\hline
\end{tabular}

The NCUA focuses its attraction and retention strategies on ensuring that credit union members have a voice in the conversion process. However, their policymaking in this realm has focused on placing tangible barriers to charter exit. Since 1998, the NCUA has undertaken through the rulemaking to clarify the process for converting a federally chartered credit union to a mutual savings bank. In part because demutualization are complex and the NCUA is creating these procedures while conversions occur, there has been frequent tension. The agency strategy has primarily been to retain regulated institutions by crafting barriers to exit the under the guise of consumer protection. There have also been more recent attempts to attract banks to the federal credit union charter. The NCUA website lists information for banks that may be interested in converting. However, it appears to be a rhetorical tool to refute bank advocacy groups contention that credit unions have a competitive advantage over banks.

Analysis of the NCUA's policy statement shows interesting evidence the NCUA engages generally and clientele and technical policy statement. $80 \%$ of the agency's statements focus on technical and clientele issues. This may be because the NCUA falls under less legislative scrutiny in the OTS or OCC. Furthermore, the NCUA at least in part views its role as being to further the credit union movement. The agency views the furthering of the credit union movement as effectually being a public-interest issue.

Turning to the speeches and testimony of the NCUA leadership there are some differing trends. When addressing Congress and the supervised institutions as the financial crisis unfolded, the NCUA became more focused on public-interest communications. This may be because there Congress increased its attention and astutely the 
agency refocused its communication so that the overall values of the financial system were reflected (see Figure 3).

Figure 3: NCUA Speeches \& Testimony 1999-2008

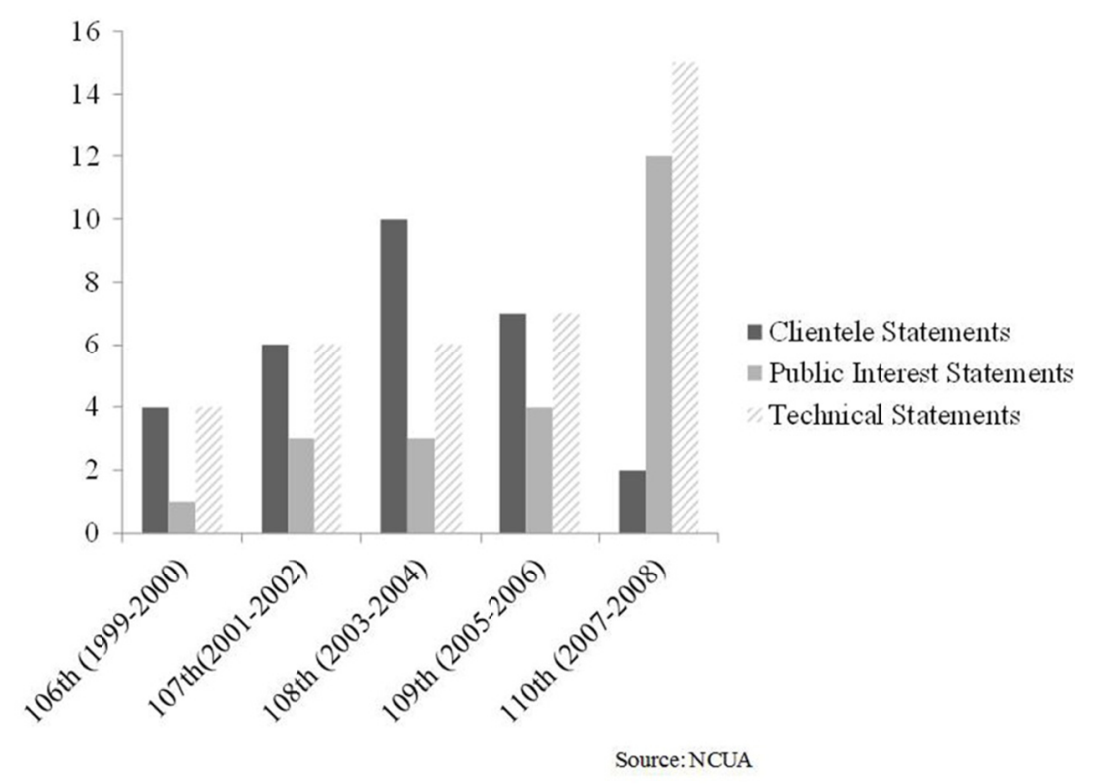

As the regulator with medium effectiveness, the NCUA represents an agency that seems to strive to balance technical guidance with clientele statements. The focus on technical guidance may occur because of perceived lower levels of technical aptitude in finance among credit union employees. The NCUA may feel that in order to prevent systemic risk they have to engage in higher levels of education of risk managers among credit unions. Nevertheless, the NCUA focus on technical guidance appears to be more relationship of coaching their supervised community than empowering it.

4.2 OCC

Table 2: Breakdown of OCC Policy Statements

\begin{tabular}{|c|c|c|c|c|c|c|}
\hline & $1999-2000$ & $2001-2002$ & 2003-2004 & 2005-2006 & $2007-2008$ & Median \\
\hline $\begin{array}{l}\text { Clientele } \\
\text { Statements }\end{array}$ & $\begin{array}{c}9 \\
24.32 \%\end{array}$ & $\begin{array}{c}\delta \\
23.53 \%\end{array}$ & $\begin{array}{c}11 \\
36.67 \%\end{array}$ & $\begin{array}{c}7 \\
15.22 \%\end{array}$ & $\begin{array}{c}0 \\
0.00 \%\end{array}$ & $23.53 \%$ \\
\hline $\begin{array}{l}\text { Public Interest } \\
\text { Statements }\end{array}$ & $\begin{array}{c}15 \\
40.54 \%\end{array}$ & $\begin{array}{c}14 \\
41.13 \%\end{array}$ & $\begin{array}{c}7 \\
23.33 \% \\
\end{array}$ & $\begin{array}{c}12 \\
26.09 \%\end{array}$ & $\begin{array}{c}28 \\
57.14 \%\end{array}$ & $40.54 \%$ \\
\hline $\begin{array}{l}\text { Technical } \\
\text { Statements }\end{array}$ & $\begin{array}{c}13 \\
35.14 \%\end{array}$ & $\begin{array}{c}12 \\
35.29 \%\end{array}$ & $\begin{array}{c}12 \\
40.00 \%\end{array}$ & $\begin{array}{c}27 \\
58.70 \%\end{array}$ & $\begin{array}{c}21 \\
42.86 \%\end{array}$ & $40.00 \%$ \\
\hline
\end{tabular}

The OCC has focused its attraction and retention efforts on Subchapter $\mathrm{S}$ status and on the preemption of federally chartered financial institutions over those chartered by states. In recent years the agency has seen its most significant charter losses occur due to increases in interest in state-charters. State regulators often market themselves as a cost-effective alternative to federal charters. The OCC has worked protect the ability to preempt 
state and local laws in order to give federally chartered financial institution a tangible advantage over those regulated by state entities. Since OCC regulated institutions have access to the capital markets through stock offerings and have fewer restrictions on the type the types of businesses they can conduct, there generally in the strongest position to attract and retain charters.

As Table 2 shows above, the breakdown of the policy statement by the OCC show a focus on technical and public interest policy statements. Approximately $80 \%$ of the policy statements were either technical or public interest oriented. Comparatively speaking this is a much greater portion than either the OTS or in CA. Furthermore only $20 \%$ of the policy statements focusing on empowering the regulated community, the OCC was more likely to at least appear not to cater to the supervised community as overtly.

Turning to the speeches and testimony of OCC leadership, there is a slightly different trend. As the financial crisis of the last decade progressed, the OCC became much less focused on clientele statements in their testimonies and speeches. This coupled with their lower failure rate give some credence to the idea that the appearance of acting in the public interest is the benefit to regulatory agencies (See Figure 6).

As the most effective agency and also the one most likely to address public interest and technical concerns with speeches and policies the OCC give some evidence that there may be validity in a theoretical model that I proposed in Figure 2. However, there may be rhetorical differences in agency action and rhetoric. The OCC may understand that legislate tours expect public interest and technical issues to be the foci of their communications and actions. The OCC may simply be more proficient at communicating with their regulated community and legislative constituencies in the better position to shepherd the resources and legal authority necessary to attract institutions and prevent them from failing. Nevertheless when one views the financial services system in terms of systemic risk the prevention of failures even at the expense of increased legal authority for supervised institutions may be a preferable situation.

\subsection{OTS}

The OTS has focused its retention and attraction strategy on commercial banks and credit unions. The mutual holding company structure which allows thrift institutions to raise capital in a manner similar to stock held bank, was an effort to keep parity among OCC regulated institutions. In conjunction with the OCC, the OTS has also worked to advocate for the subchapter S structure for banks. Subchapter S greatly reduces the tax burden that banks pay by pushing taxation to the shareholder level. Typically these banks have been smaller institutions and by law have a 150 shareholder limit. However, there is an exemption for shareholders within the same family which greatly expands the number of shareholders. Subchapter S allows both thrift and commercial banks to counter federally chartered credit union's tax exemption.

Table 3: Breakdown of OTS Policy Statements

\begin{tabular}{|c|c|c|c|c|c|c|}
\hline & $1999-2000$ & $2001-2002$ & 2003-2004 & 2005-2006 & $2007-2008$ & Median \\
\hline $\begin{array}{l}\text { Clientele } \\
\text { Statements }\end{array}$ & $\begin{array}{c}1 \\
4.55 \% \\
\end{array}$ & $\begin{array}{c}5 \\
41.67 \%\end{array}$ & $\begin{array}{c}5 \\
50.00 \%\end{array}$ & $\begin{array}{c}12 \\
54.55 \%\end{array}$ & $\begin{array}{c}1 \\
2.38 \%\end{array}$ & \multirow[t]{2}{*}{$41.67 \%$} \\
\hline $\begin{array}{l}\text { Public Interest } \\
\text { Statements }\end{array}$ & $\begin{array}{c}\$ \\
36.36 \%\end{array}$ & $\begin{array}{c}3 \\
25.00 \%\end{array}$ & $\begin{array}{c}1 \\
10.00 \%\end{array}$ & $\begin{array}{c}5 \\
22.73 \%\end{array}$ & $\begin{array}{c}33 \\
78.57 \%\end{array}$ & \\
\hline $\begin{array}{l}\text { Technical } \\
\text { Statements }\end{array}$ & $\begin{array}{c}13 \\
59.09 \%\end{array}$ & $\begin{array}{c}4 \\
33.33 \%\end{array}$ & $\begin{array}{c}4 \\
40.00 \%\end{array}$ & $\begin{array}{c}5 \\
22.73 \%\end{array}$ & $\begin{array}{c}8 \\
19.05 \%\end{array}$ & \multirow[t]{2}{*}{$33.33 \%$} \\
\hline Total & 22 & 12 & 10 & 22 & 42 & \\
\hline
\end{tabular}

Turning now to the breakdown of OTS's policy interventions, there is a trend in the OTS towards clientele oriented guidance. As Table 3 illustrates, OTS is slightly more likely to issue guidance that enhances the profitability of the regulated institutions.

An examination of the speeches and testimony of the OTS also shows a similar trend. Speeches and testimony by 
the leadership of the OTS became more focused on clientele issues as the decade progressed. This occurred in concert with increased legislative attention and focus on terminating the agency or drastically restructuring its regulatory function.

Figure 5: OTS Speeches \& Testimony1999-2008

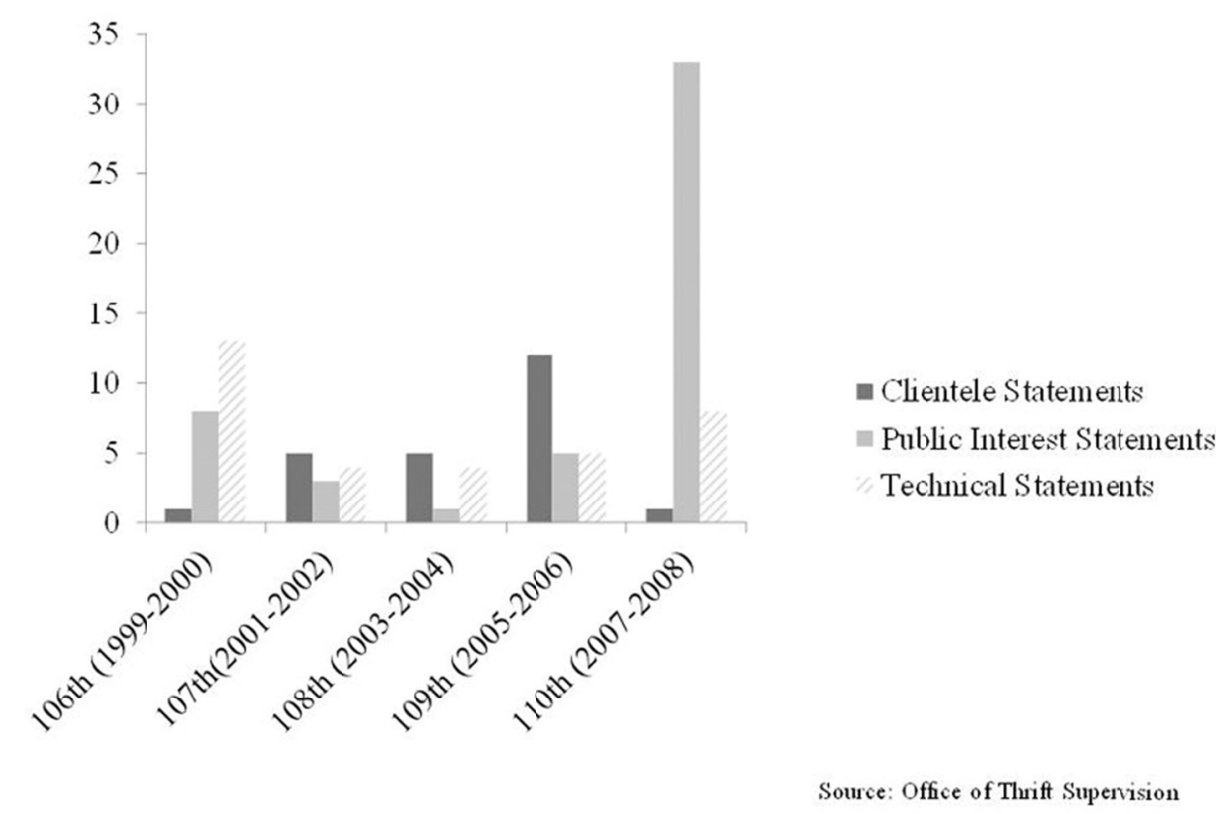

Since the $106^{\text {th }}$ Congress, OTS speeches and testimony have been increasingly focused on empowering their regulated communities this is particularly surprising when one considers that during 2007-2008 the American financial system came under considerable stress. It is likely that this represents a last-ditch effort by the OTS to stay in existence while many decision-makers were focused on merging the OTS with OCC.

As the least effective of the three regulators that comprise this case study, there do seem to be some lessons to be learned from OTS's focus on clientele policies and communications. It may be that at the very least by focusing on empowering their regulated community, the agency fell out of favor with legislate tours. At most, by focusing on empowering their supervised communities he OTS lost perspective and became ineffective at implementing public interest in technical policies.

\section{Discussion}

In 2010, Congress passed and President Obama signed the Dodd-Frank Wall Street Reform and Consumer Protection Act. One of the major functions of this bill structured a new consumer-oriented financial services regulator to counter-balance the traditional and more industry-focused regulators. The Consumer Financial Protection Bureau (CFPB) has attempted to undercut regulatory pathologies that have led regulators to focus on empowering their supervised communities. The CF PB appears to be structured to bolster the overall regulatory systems focus on public interest in technical policies. If this is the case this may very well lead to the deemphasizing of the public interest in technical policymaking among the traditional banking regulators (CFPB Website, 2012).

Returning to my initial concerns in Figure 2, and can map the agencies that were the subject of this analysis onto the theoretical model. In Figure $\mathbf{6}$ one can see that the OCC generally engaged more public interest in technical policymaking and this increased its effectiveness. Perhaps the most important finding that led to a revision of the theoretical model after this analysis is that there is no linear relationship between effective regulators and the spectrum on one end of clientele policies and on the other end of public interest policies. Rather agencies that engage in high levels of technical and public interest policies appear to be more effective than those who engage in clientele policies (see revised model in Figure 6 below. 
Figure 6: Revised Model of Regulatory Emphasis and Effectiveness Among Financial Services Regulators

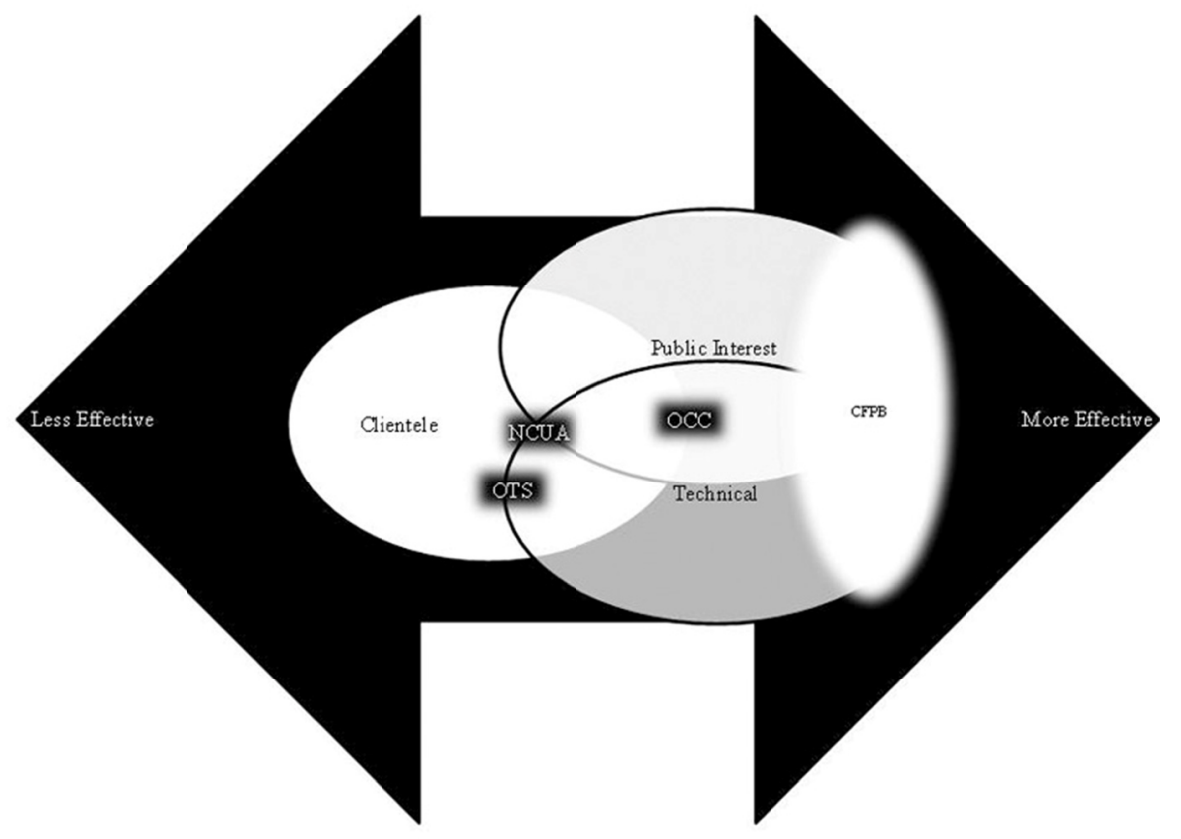

While the NCUA engaged in regulatory interventions that were balanced between clientele, public interest, and technical concerns. The NCUA had medium effectiveness among the agencies studied in this analysis. The now defunct OTS generally engaged in clientele and technical policymaking and was the least effective regulator. Finally, I have also included the CF PB on this diagram the one can see their policy foci There is some evidence that the model is proposed in figure 2 does have some theoretical validity. Regulators and financial services sectors where there is considerable overlap of jurisdiction that have tended towards considering technical and public interest policy interventions have generally been more effective at preventing the failures of the regulated institutions. However it appears that balance is an important aspect in maintaining regulatory effectiveness. Both the NCUA and OCC have a balance between public interest in technical policymaking with varying levels of clientele interventions intermingled while the OTS is much more focused on clientele interventions. This was a surprising finding based on the theoretical model. It appeared that effective regulators don't just simply engage in higher level of public interest interventions, but are in fact able to better balance the many complex requirements that the policy context places on the agency. Therefore, the analysis of the NCUA, OCC, and OTS partially refutes hypothesis that drove this research. Nevertheless there does appear to be some validity to the overall theoretical model.

Future research relating to a theory of public interest regulation should focus on regulatory agencies that exist outside of the complex and highly resourced federal level of financial services policy. There are many aspects to financial services regulation that are unusual if not unique. The dynamic of self-funding and even more novel structure of regulatory competition could you the application of the theoretical model. In order to understand if this model is generalizable future researchers should focus on understanding public-interest's relationship to mission thereby serving to better explain regulatory effectiveness.

\section{References}

Aberbach, J. D. (1990). Keeping a Watchful Eye: The Politics of Congressional Oversight. Washington, DC: The Brookings Institution.

Baumgartner, F., \& Jones, B. D. (2005). The Politics of Attention: How Government Prioritizes Problems. Chicago: University of Chicago.

Bernstein, M. (1955). Regulating Business by Independent Commission. Princeton, NJ: Princeton University Press.

Blair, C., \& Kushneider, R. (2006). Challenges to the Dual Banking System: The Funding of Bank Supervision. FDIC Banking Review, 18. 
Boehm, F. (2007). Regulatory capture revisited - Lessons from economics of corruption. Working Paper, Research Center in Political Economy, Universidad Externado de Columbia. Retrieved from http://www.icgg.org/downloads/Boehm\%20-\%20Regulatory\%20Capture\%20Revisited.pdf

Buiter, W. (2008). Lessons From the North American Financial Crisis. Paper presented at the The Role of Money Markets. Retrieved from http://newyorkfed.org/research/conference/2008/rmm/buiter.pdf

Consumer Financial Protection Bureau. (2012). Website of the Consumer Financial Protection Bureau. Retrieved from http://www.consumerfinance.gov/the-bureau/creatingthebureau/Accessed 9/2/2012

Dell'Ariccia, G. a. R. M. (2001). Competition Among Regulators. International Monetary Fund. Retrieved from http://www.imf.org/external/pubs/ft/wp/2001/wp0173.pdf

Eisner, M. A. (2000). Regulatory Politics in Transition. Baltimore \& London: The Johns Hopkins University Press.

Estache, A. a. D. M. (1999). Politics, Transaction Costs, and the Design of Regulatory Institutions. The World Bank. Retrieved from http://elibrary.worldbank.org/content/workingpaper/10.1596/1813-9450-2073

Feldmann, S. E. (2005). Bureaucratic Expertise and Learning from Interest Groups. Northwestern University. Retrieved from http://egp.vcharite.univ-mrs.fr/pet/viewabstract.php?id=292

Goodsell, C. (2011). Mission Mystique: Belief Systems in Public Agencies. Washington, DC: CQ Press.

Goodsell, C. (Ed.). (1990). Public administration and the public interest. Newbury Park, CA: Sage Publications, Inc.

Hammond, T. H., \& Knott, J. H. (1988). The Deregulatory Snowball: Explaining Deregulation in the Financial Industry. The Journal of Politics, 50(1), 3-30. http://dx.doi.org/10.2307/2131038

Hardy, D. (2006). Regulatory Capture in Banking. International Monetary Fund. Retrieved from http://www.imf.org/external/pubs/ft/wp/2006/wp0634.pdf

Hoffmann, S. (2001). Politics and Banking; Ideas, Public Policy, and the Creation of Financial Institutions (1st ed.). Baltimore, Maryland: The Johns Hopkins University Press.

Hoffmann, S. a. M. K. C. (2010). Mission Expansion in the Federal Home Loan Bank System. Albany, NY: SUNY Press.

Johnson, C. (2010). The Foreclosure of America: The Inside Story of the Rise and Fall of Countrywide Home Loans, the Mortgage Crisis, and the Default of the American Dream. [Book Review]. Academy of Management Learning \& Education, 9(1), 150-152. Retrieved from $\mathrm{http} / / /$ connection.ebscohost.com/c/book-reviews/48661200/foreclosure-america-inside-story-rise-fall-countr ywide-home-loans-mortgage-crisis-default-american-dream

Katzmann, R. A. (1980). Regulatory Bureaucracy: The Federal Trade Commission and Antitrust Policy. Cambridge, Mass: MIT Press.

Kaufman, G., \& Scott. K. (2003). What Is Systemic Risk, and Do Bank Regulators Retard or Contribute to It? The Independent Review, VII(3), Winter, 2003, ISSN 1086-1653, Copyright (C) 2003, pp. 371-391. Retrieved from http://www.independent.org/pdf/tir/tir_07_3_scott.pdf

Laffont, J. J., \& Tirole, J. (1991). The Politics of Government Decision-Making: A Theory of Regulatory Capture. Quarterly Journal of Economics, 1089-1127. http://dx.doi.org/10.2307/2937958

Martimort, D. (1999). The life cycle of regulatory agencies: dynamic capture and transaction costs. Review of Economic Studies, 66, 929-947. http://dx.doi.org/10.1111/1467-937X.00114

McCabe, D. L., Butterfield, K. D., \& Trevino, L. K. (2006). Academic Dishonesty in Graduate Business Programs: Prevalence, Causes, and Proposed Action. Academy of Management Learning \& Education, 5(3), 294-305. http://dx.doi.org/10.5465/AMLE.2006.22697018

Meier, K. J. (1985). Regulation: Politics, Bureaucracy and Economics. New York: St. Martin's Press.

Moe, R. C. (1991). Political Science and the Savings and Loan Crisis: An Introduction. PS: Political Science and Politics, 24(3), 432-433. http://dx.doi.org/10.2307/420083

National Credit Union Administration Website. (2010). Retrieved from http://www.ncua.gov

The OCC's Preemption Rules. (2006).

Office of the Comptroller of the Currency Website. (2011). Retrieved from http://www.ots.gov 
Office of Thrift Supervision Website. (2011).

Scott, K. E. (1977). The Dual Banking System: A Model of Competition in Regulation. Stanford Law Review, 30(1), 1-50. http://dx.doi.org/10.2307/1228174

Smyth, R. a. S., M. (2009). Public Interest and Regulatory Capture in the Swedish Electricity Market. Centre for Regulation and Market Analysis, University of South Australia, Australia.

States, T. N. C. o. t. C. o. t. F. a. E. C. i. t. U. (2011). The Financial Crisis Inquiry Report. New York.

Thomas, C., Soule, A., \& Davis, T. (2010). Special Interest Capture of Regulatory Agencies: A Ten-Year Analysis of Voting Behavior on Regional Fishery Management Councils. Policy Studies Journal, $38(3), 447$. http://dx.doi.org/10.1111/j.1541-0072.2010.00369.x

Whalen, R. C. (2008). The Subprime Crisis: Cause, Effect and Consequences. Networks Financial Institute Policy Brief No. 2008-PB-04.

Woodward, S. (1998). Regulatory Capture at the U.S. Securities and Exchange Commission. Paper presented at the The Milken Institute Conference on Capital Markets. Retrieved from http://www.sandhillecon.com/pdf/RegulatoryCapture.pdf

Yin, R. (2009). Case Study Research: Design and Methods. Sage Publications, Thousand Oaks, CA.

\section{Copyrights}

Copyright for this article is retained by the author(s), with first publication rights granted to the journal.

This is an open-access article distributed under the terms and conditions of the Creative Commons Attribution license (http://creativecommons.org/licenses/by/3.0/). 